\title{
Activists Against Autocrats: TSMO Networks and Democratic Diffusion
}

\author{
Jonathan Pinckney ${ }^{1}$ and John Joseph Chin ${ }^{2 *}$ \\ ${ }^{1}$ Program on Nonviolent Action, United States Institute of Peace, Washington, DC, United States, ${ }^{2}$ Center for International \\ Relations and Politics, Carnegie Mellon University, Pittsburgh, PA, United States
}

\section{OPEN ACCESS}

Edited by:

Jan Matti Dollbaum,

University of Bremen, Germany

Reviewed by:

Jackie Smith,

University of Pittsburgh, United States

Svend-Erik Skaaning,

Aarhus University, Denmark

*Correspondence:

John Joseph Chin

jjchin@andrew.cmu.edu

Specialty section: This article was submitted to

Peace and Democracy,

a section of the journal

Frontiers in Political Science

Received: 04 May 2021

Accepted: 20 July 2021

Published: 16 September 2021

Citation:

Pinckney J and Chin JJ (2021) Activists Against Autocrats: TSMO Networks and Democratic Diffusion.

Front. Polit. Sci. 3:705223.

doi: 10.3389/fpos.2021.705223
Do transnational social movement organizations (TSMOs) promote the international diffusion of democracy? If so, how? Scholars of democratization have studied a plethora of international factors in the spread of democracy, including geographic or regional proximity, colonial history, trade and alliance networks, and joint intergovernmental organization (IGO) memberships. Few have studied the role of TSMO networks in democratic diffusion. We theorize that TSMOs empower and connect civil societies and thus promote democracy from the "bottom up." Leveraging a new TSMO Dataset and data on the dimensions of democracy from the Varieties of Democracy project over the 1953-2013 period, we find that TSMOs promote democratic diffusion. TSMOs are strongest at diffusing participatory democracy. TSMOs also contribute to the diffusion of electoral democracy but do so by promoting the diffusion of freedom of association and freedom of expression rather than elections.

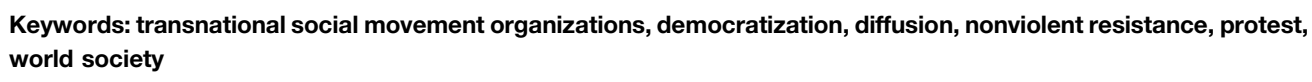

\section{INTRODUCTION}

What role do transnational social movement organizations (TSMOs)-international nongovernmental organizations (INGOs) dedicated to promoting social or political change-play in democratic diffusion? ${ }^{1}$ In this article, we leverage a new Transnational Social Movement Organizations Dataset from 1953-2013 and data from the Varieties of Democracy (V-Dem) project to address these questions. We find that TSMOs have a robust positive effect on democratization, but that identifying this effect requires disaggregating our concept of democracy into more refined dimensions.

Most prior studies of democratic diffusion examine whether a single, highly aggregated dimension of democracy (i.e., a "polity" or electoral democracy score) diffuses internationally. By leveraging much more disaggregated V-Dem data on alternative dimensions and components of democracy, we take a first step towards unpacking the "black box" of mechanisms by which democracy diffuses. This new data allows us to examine our main theoretical claim, namely, that TSMOs promote democracy from the "bottom up." We argue that activists who are embedded in democratic TSMO networks promote democratic civil societies, diffuse participatory democratic norms, and are more effective in mobilizing against autocrats. TSMOs' contribution to democratic diffusion therefore complements

\footnotetext{
${ }^{1}$ Some scholars conflate INGOs and TSMOs. Although the correlation between total INGO and TSMO country memberships is high $(\rho \approx 0.95)$, TSMOs are a small subset of INGOs (Smith 1996; Sikkink and Smith 2002). In our data, TSMOs account for about a quarter of INGOs in the average country-year. Many INGOs promote technical cooperation rather than political change. Although the larger population of INGOs may also impact democracy, we focus on TSMOs.
} 
but is analytically distinct from the "top-down" processes emphasized in prior literature. Whereas inter-governmental organization (IGO) networks may facilitate high-level diplomacy to socialize or coerce elites from other countries to hold free and fair elections, TSMO networks empower nongovernmental pro-democracy activists and promote democratic mobilization in the streets.

Although prior quantitative studies of democratic diffusion have neglected TSMOs, the role of certain TSMOs in promoting human rights has been extensively studied (Hafner-Burton and Tsutsui 2005; Murdie and Davis 2012; Kim 2013). The qualitative literature is also rich with examples of TSMOs helping diffuse democracy. For example, consider Servicio Paz y Justicia (SERPAJ), a human rights TSMO established in 1974 with the help of U.S. and European peace activists with the goal of defending political prisoners in the midst of the dirty wars. The SERPAJ network set up eight national chapters across Latin America from 1974-1982 to resist military rule. SERPAJ's first General Coordinator, Adolfo Pérez Esquivel, sponsored civil resistance and helped form the Mothers of the Plaza de Mayo in Argentina in 1977. In short, SERPAJ was a "movement midwife" for resistance to bureaucratic authoritarianism in the region (Pagnucco and McCarthy 1999). In a similar way, TSMOs such as the International Helsinki Federation for Human Rights (IHF) were part of the "transnational Helsinki network" that facilitated nonviolent resistance against communist regimes in Eastern Europe since 1976, which culminated in the revolutions of 1989 (Davies 2014, 152-153).

Are the SERPAJ and IHF examples anomalies or generalizable? Through a series of spatial regression models in a global sample of countries from 1953 to 2013, we show that TSMOs do promote cross-national democratic diffusion, as constructivists have long argued, ${ }^{2}$ even when controlling for alternative diffusion networks and other major confounders. Furthermore, we show that TSMOs diffuse distinct aspects of democracy, specifically participatory democracy, freedom of expression (including freedom of the press), and freedom of association. To the extent that western governments have been overwhelmingly focused on free elections and neglected other critical democratic elements of democracy promotion efforts since the 1990s (e.g., Carothers 2015), TSMO networks play an under-appreciated role in promoting non-electoral components of democracy.

These findings have implications for studies of democratic diffusion, transnational activist networks, and world polity theory. They show not only that "world society" and TSMOs matter for global democracy in measurable ways, but also offer a corrective to the widely held assumption of world polity theorists that convergence towards democracy is a product of modernization, emulation, or value-neutral acceptance of a homogenous set of global secular-rational values. ${ }^{3}$ Democracy

${ }^{2}$ Our emphasis on the importance of transnational social movements for democratic diffusion parallels qualitative accounts by Markoff (1996), Keck and Sikkink (1998), and Della Porta (2014).

${ }^{3}$ For classic works of world polity theory, see Thomas et al. (1987), Meyer et al. (1997). is not simply a political technology passively adopted by autocratic elites or "learned" via socialization. Instead, discord by civil society activists, at least in part, drives convergence in the "world polity."

We proceed as follows. First, we review the empirical democratic diffusion literature, which has heretofore neglected TSMOs. We then derive testable hypotheses about how TSMO networks diffuse democracy. Next, we present our data and modeling strategy. Third, we present our results and show evidence of their robustness. We conclude with implications for policymakers and future research.

\section{LITERATURE REVIEW: THE TRANSNATIONAL SOCIAL MOVEMENT ORGANIZATION-DEMOCRATIC DIFFUSION NEXUS}

Since the end of the Cold War, scholars of democratization have studied a growing number of international factors in democracy's spread (Haggard and Kaufman 2016, 136-137). Samuel Huntington (1991) popularized the idea that contagion helps explain why democratic transitions cluster spatially and temporally in "waves." Scholars have long observed that democratic transitions cluster regionally, ${ }^{5}$ whether in Latin America (Mainwaring and Pérez-Liñán 2007; Weyland 2014), Eastern Europe (Kopstein and Reilly 2000; Bunce and Wolchik 2011), or the Middle East (Bamert, Gilardi, and Wasserfallen 2015). After a first wave of democratic diffusion studies from the late 1990 s to mid-2000s, ${ }^{6}$ it became standard in studies on the causes of democratization to control for either global or regional democracy trends (i.e., average democracy) to account for such diffusion.

Among studies of democratic diffusion, there has been a focus on geographic contiguity: the notion that neighbors that share borders are more likely to become "democratic dominoes" (Brinks and Coppedge 2006; Gleditsch and Ward 2006; Leeson and Dean 2009). However, recognizing that "space is more than geography" (Beck and Beardsley, 2006), scholars have more recently explored a number of non-geographic distance measures that may also promote democratic diffusion, such as democratic ties via colonial networks (Wejnert 2005, 2014; Coppedge et al., 2016), university education networks (Spilimbergo 2009; Gift and Krcmaric 2017), alliance networks (Zhukov and Stewart 2013), and trade networks (Torfason and Paul, 2010; Ahlquist and Wibbels 2012). Other non-geographic

${ }^{4}$ Some scholars use the terms "world polity" and "world society" interchangeably, yet we see IGOs as part of the "world polity" and TSMOs as part of "world society." They have potentially distinct motives and effects. See Cole (2017).

${ }^{5}$ On the importance of regional dynamics (as opposed to global trends) for the spread of democracy, see Bunce (2000), Gleditsch, 2002 (ch. 2), and Mainwaring and Pérez-Liñán (2007).

${ }^{6}$ For early tests of democratic diffusion from this first wave of studies, see Starr (1991), O’Loughlin et al. (1998), Starr and Lindborg (2003), Doorenspleet 2005 (ch. 8), and Wejnert (2005). 
factors scholars have considered include shared regime type (Goldring, 2020), hegemonic shocks (Gunitsky 2014, 2017), and the relative recent economic performance of democracies and non-democracies (Miller 2016). Because many overlapping contiguity networks enmesh countries simultaneously, it is near impossible ex ante to know through which of these many networks democracy diffuses. This "conflicting neighbor problem" (Zhukov and Stewart 2013) makes it incumbent on scholars to be careful in how they construct models of democratic diffusion. To our knowledge, no prior studies of democratic diffusion have considered TSMO networks. Is it possible that some of the effects attributed to other networks actually are due to TSMOs?

The neglect of TSMOs in the democratic diffusion literature to date stands in stark contrast to IGOs. Jon Pevehouse famously argued that regional IGOs promote both democratic transitions and consolidation. In his theory, democratic diffusion largely comes from "above" as IGOs socialize and cajole their member states into adopting and locking in democratic reforms (Pevehouse 2002, 2005). New democracies may even join democratic IGOs to use "sovereignty costs" of membership to "lock in liberal policies and signal their intent to consolidate democracy" (Mansfield and Pevehouse 2006; Hafner-Burton, Mansfield, and Pevehouse 2015). Testing his theory for the 1945-1992 period, Pevehouse constructed a spatial lag variable that measured the average democracy level of the most democratic political, economic, or social IGO that a country was a member of. Using this measure over the 1972-2006 period, Teorell (2010, 80-82) found that regional IGOs promoted upswings in democracy (transitions) but had no effect preventing downswings in democracy (consolidation).

However, some scholars remain skeptical that IGOs effectively or consistently promote democratic diffusion. One concern is that "democratic" IGOs only inconsistently uphold democratic values, as they are less likely to punish norm violations in strategically important members, may be insulated from non-state actors that could hold member states accountable, or simply lack coercive enforcement powers needed to roll back authoritarian reversals in transitional democracies in the short run (Boniface 2002; Levitt 2006; Hawkins 2008; Donno 2010; Poast and Urpelainen 2015). A final concern is that IGOs are epiphenomenal due to democratic selection bias: states get to choose their IGO memberships. Nygård (2017) shows that dictators are less likely to liberalize in the first place if they are members of highly interventionist IGOs, making diffusion less likely.

Although some democratic diffusion likely comes from "above," there are also good reasons to expect democratic diffusion to come from "below." If IGOs promote "trickle down" democratization by influencing elites, TSMOs should lift democratic boats on a tide of activated civil society. Among world polity theorists, IGOs and INGOs are often thought of as two sides of the same emergent democratic "global culture." However, most theories of democratic diffusion focus on only one side of that coin. Among prior studies of democratic diffusion, only one -- by Torfason and Paul (2010) -- even considers INGOs theoretically as carriers of democratic values. However, empirically those authors control for IGO network effects but not INGO network democratic diffusion effects.

\section{THEORIZING DEMOCRATIC DIFFUSION THROUGH TRANSNATIONAL SOCIAL MOVEMENT ORGANIZATIONS}

\section{The Rise and Roles of Transnational Social Movement Organizations}

TSMOs are the roughly one-quarter of all international NGOs with the explicit goal of promoting social or political change. ${ }^{7}$ TSMOs include organizations that seek to promote human rights, such as Amnesty International or Human Rights Watch, environmental movements such as Greenpeace, and women's rights groups such as The International Alliance for Women. Although all TSMOs are INGOs, not all INGOs are TSMOs. What distinguishes TSMOs from the larger set of INGOs is their focus on achieving political or social change that drives them to explicitly engage in cross-national advocacy. In contrast, many INGOs are professional organizations, focused on coordinating standards across borders, or even recreational groups such as the World Leisure Organization.

There has been a dramatic rise in the number and reach of TSMOs in recent decades. ${ }^{8}$ While there were fewer than 200 TSMOs globally in 1961, by 2011 there were nearly 1800. The median number of TSMOs per country has likewise risen approximately ten-fold since the 1970s, from about 25 per country in the mid-1970s to 225 by 2010 . TSMOs have also changed in terms of their focus areas and organizational structures. While historically TSMOs tended to adopt a "federated" structure, with a single central base in their home country managing local affiliates, more recently most TSMOs have adopted a "coalitional" structure that lack a single central organizing hub and instead give significant autonomy to local branches (Smith 2008, 124). Their change-driven missions and grassroots political activism have implications for how we should expect TSMOs to encourage democratic diffusion.

The necessity of mobilizing members to pursue their goals of social change make it crucial for TSMOs to foster strategic frames and group identities (Smith 2002). These processes of framing and identity formation often lead to a set of shared norms and ideals across widely divergent national contexts, in particular socializing members in a concern for an environment in which their activism is free from the repression or interference of the state. TSMOs are not just sites of assistance from one set of members to another, for instance from wealthy activists in the global North to struggling norm entrepreneurs in the global South, but increasingly egalitarian forums for the diffusion of shared ideas and norms. ${ }^{9}$ Just as domestic civil society structures can act as sites for the growth of political knowledge, advocacy skills, and norms of proper social and political behavior, so

${ }^{7}$ Per the TSMO dataset, described in more detail in the data section. For more on the concept and evolution of the TSMO population over time, see Sikkink and Smith (2002), Smith and Wiest (2005), and Smith et al. (2017).

${ }^{8}$ On the growth of INGOs and "world society" more broadly, see Boli and Thomas (1999) and Boli and Thomas (1997).

${ }^{9}$ Although most TSMOs continue to be headquartered in the global North, the share of TSMOs with headquarters in the global South has increased in recent decades. This is especially true of newer TSMOs. See Smith et al. (2018), (387-388) 
TSMO members and affiliates share similar knowledge, skills, and social and political norms across borders.

TSMOs are crucial in Keck and Sikkink (1998) famous "boomerang model" of transnational advocacy networks (TANs). Through their links with members on the ground in repressive states, TSMOs with members in more open and democratic societies are frequently at the forefront of pressuring their governments to impose costs on repressive regimes. In this model, however, TSMO networks are primarily useful as carriers of information (about abuses) and as lobbying groups pressuring democratic governments. In the classic TAN model, TSMO networks embody the "power of the powerless." Given a "blockage" that prevents civil society and domestic NGOs to achieve their goals by themselves, the power of INGOs primarily lies in their ability to motivate action by governments and IGOs. In our view, TSMOs' role in promoting the diffusion of democracy may in fact be more potent and involve mechanisms other than simply mobilizing state or IGO power.

\section{How Transnational Social Movement Organizations Promote Democratic Diffusion}

There is ample existing evidence that TSMOs are important vectors for transnational diffusion of norms and even formal political institutions. For example, diffusion through INGO networks devoted to women's rights promoted the diffusion of gender mainstreaming bureaucracies (True and Mintrom 2001). The international women's movement was also crucial for the diffusion first of women's suffrage and later of female representation in government (Paxton, Hughes, and Green 2006). Diffusion through INGOs played a key role in changing environmental policy in Japan, ultimately resulting in a movement that shaped the signing of the Kyoto Treaty (Reimann 2001). Human rights INGOs also played a central role in the diffusion of national human rights institutions (Kim 2013).

Based on the character of TSMOs as sketched above and the findings on TSMO diffusion on specific issues, we expect that there are three general mechanisms by which TSMOs diffuse democracy. First, TSMOs indirectly promote other causes of democratization. Second, TSMOs directly strengthen domestic civil societies. They are "brokers" for the flow of norms and resources from more democratic states to less democratic states (Schmitz 2004; Tarrow 2005, 190-194). TSMO members can benefit not only materially but also from specialized training in strategies of resistance (GalloCruz, 2012). Thus, TSMO participation equips and motivates local members to advocate for change in their country. Third, TSMOs are avenues for flows of information about abuses of human rights and democratic freedoms from less democratic countries to more democratic countries, which in turn helps set the agenda of those democratic countries and international organizations to put pressure on the less democratic country to make changes, consistent with the classic "boomerang model."

Participation in a TSMO can encourage local bottom-up civic activism in many diverse issue areas from indigenous rights to children's rights, not all of which are explicitly designed to promote democracy but that may do so as a by-product of their seeking other social or political goals. ${ }^{10}$ For example, many TSMOs seek to promote education, which itself is believed to be an important determinant of democracy. ${ }^{11}$ Some TSMOs focused on other issues evolve into overt prodemocracy movements. The Green Belt Movement, a Kenyanheadquartered TSMO which began in 1977 with a focus on environmental protection and women's rights in Kenya, had by the late 1980s become more explicitly political and antiauthoritarian (Cockram, 2017). ${ }^{12}$ TSMOs also play an important role in promoting equitable economic development ${ }^{13}$, ending civil wars ${ }^{14}$, and achieving international peace $^{15}$, all of which should facilitate democratization (Russett and Oneal 2001; Mandelbaum 2002).

Most successful democratic transitions since World War II have entailed bottom-up civic action. Absent a sustained challenge from below, autocratic political elites are unlikely to democratize. ${ }^{16}$ While membership in democratic IGOs may

${ }^{10}$ For example, Guatemalan indigenous rights leader Rigoberta Menchú won a Nobel Peace Prize in 1992 for her work with the Peasant Unity Committee (CUC), an affiliate of the regional TSMO known as the Latin American Coordination of Rural Organizations (CLOC). The latter became part of an increasingly global peasant rights movement under the banner of a cross-regional TSMO La Via Campesina with affiliate NGOs in 81 countries (Martinez-Torres et al., 2010). The CUC was among a growing complex of peasant groups that promoted the demilitarization of rural local communities in the 1980s (Handy 1994). Peasant activists joined mass protests with other social organizations that reversed the attempted self-coup by President Serrano Elias in May 1993 and helped install Ramiro de León Carpio, the human rights OMBUDSMAN, as president. This example highlights how TSMOs may promote democracy indirectly over many years of activism at the local level long before ever explicitly mobilizing for electoral democracy.

${ }^{11}$ Indian children's rights activist Kailash Satyarthi, who won a Nobel Peace Prize in 2014, founded the TSMO network Global Campaign for Education, which now has member organizations in over 100 countries around the world.

${ }^{12}$ Wangari Maathai founded the National Council of Women of Kenya in 1964, itself an affiliate of a women's rights TSMO, which grew into its own TSMO the Green Belt Movement, which itself was associated with INGOs such as George Soros' Open Society Institute. For a review of transnational environmental activism, see Ignatow (2012).

${ }^{13}$ For example, micro-credit pioneer Muhammad Yunus, the founder of Grameen Bank in Bangladesh, also established a TSMO, Grameen Trust, which has provided capital and training to partner groups in dozens of other countries. Yunus won the Nobel Peace Prize in 2006 for these contributions to economic development around the globe.

${ }^{14}$ For example, Women of Liberia Mass Action for Peace helped bring an end to the Liberian civil war in 2004 by bringing together the Christian-led Women in Peacebuilding Network (WIPNET) and Muslim women to campaign for the war's end. The group was a member of the West Africa Network for Peacebuilding (WANEP), a TSMO founded in 1998 in Ghana. Liberian peace activist Leymah Gbowee, co-founder of this Liberian peace movement, won the Nobel Peace Prize in 2011. Gbowee also founded a new TSMO, Women Peace and Security Network-Africa (WIPSEN-Africa) in 2006 with members in five states (Ghana, Ivory Coast, Liberia, Nigeria, Sierra Leone) (Gbowee 2011).

${ }^{15}$ Several TSMOs have won the Nobel Peace Prize, including Amnesty International in 1977 (Clark 2001), International Physicians for the Prevention of Nuclear War in 1985, and The International Campaign to Ban Landmines in 1997.

${ }^{16} \mathrm{On}$ the importance of mass action in democratization, see for example Chenoweth and Stephan (2011), Celestino and Gleditsch (2013), Bayer et al. (2016), and Pinckney (2020). 
make decision makers less likely to repress challenges from below, TSMOs should strengthen civil society, increase associational activity (Schofer and Longhofer 2011), and make the threat or use of civic action and political dissent more credible. ${ }^{17}$ For example, citizens of countries with more TSMO memberships are more likely to sign a petition or participate in a protest (Dodson 2015, 2016). Such nonviolent protest campaigns may themselves diffuse across borders (Beissinger 2007; Braithwaite and Kucik 2015; Gleditsch and Rivera 2017), and when successful lead to regime change and more durable democracy. Connections to TSMO networks, in short, can be empowering. For example, environmental TSMO links have promoted the growing number and influence of environmental NGOs in China (Chen 2010), which in turn has driven a recent wave of environmental protest (Steinhardt and Wu 2016).

TSMO connections should make activists in democracies more likely to advocate that international organizations and democratic governments put pressure on non-democratic governments. For example, transnational NGO networks-with the support of external INGO partners-promoted democratization in Indonesia in the late 1990s. In addition to engaging in election monitoring, they were also at the forefront in pressing for "good governance", anti-corruption reforms, and human rights (Jemadu 2004). In the 1980s and 1990s, human rights TSMO networks incentivized outside states "to exert pressure on, and thus to raise the costs of repression for, the governments and militaries of both El Salvador and Guatemala." In the Guatemalan case, for example, Frank LaRue set up a small but effective INGO, the Center for Legal Action and Human Rights (CALDH), in 1990 with offices first in Washington, DC, and then in Guatemala. CALDH kept up political pressure in Washington to act, as LaRue frequently gave congressional testimony (Burgerman 1998).

The ability of TSMOs to promote democratic diffusion should logically be stronger whenever a target country: 1) is more deeply embedded in "world society" and its citizens are members in a greater number of TSMOs; and 2) has more democratic TSMO network neighbors. TSMOs cannot (directly) promote democracy in countries where they do not operate or have members, and thus the mechanisms we outline should be expected to be weaker in an isolated country like North Korea (fewer than 50 TSMO memberships in 2013) compared to a country like Russia (with over 500 TSMO memberships in 2013). TSMOs also will not promote democracy if the members of the TSMO do not represent or carry democratic values. Because a majority of all TSMOs are concerned with the promotion of human rights, "world polity" theorists assume that INGOs and TSMOs tend to embody democratic norms of universalism, individualism, voluntaristic authority, rational progress, and world citizenship (Boli and Thomas 1997, 180). Given the diversity of the TSMO population, we expect that commitment to democratic values and thus "democratic

${ }^{17}$ Revolutionary threats "from below" also play a key role in conventional political economy models of democratization. See, e.g., Boix (2003) and Acemoglu and Robinson (2006). signals" sent to target countries will be stronger when more TSMO members are from more consolidated democracies.

\section{What Kind of Democracy do Transnational Social Movement Organization Networks Diffuse?}

Just as they diffuse human rights institutions, gender mainstreaming bureaucracies, and climate change policies, we argue that TSMOs also diffuse democracy. But what kind of democracy do TSMOs spread? While scholars have long noted the multidimensionality of democracy, ${ }^{18}$ this acknowledgment has rarely made it into empirical practice. Most quantitative studies of democratic diffusion still rely on unidimensional (or even binary) indexes such as Polity IV. This obscures the richness and complexity of democracy, in particular aspects of democracy that go beyond the core institution of free and fair elections (Collier and Levitsky 1997; Coppedge et al., 2011).

Given a majority of all TSMOs have the promotion of human rights or democracy as a main goal, we expect that many TSMOs are committed to electoral democracy. Democratic donor states, after all, played a significant role in promoting the growth of TSMOs (Reimann 2006). A majority of TSMOs are also headquartered in the global North, close to the elite centers focused on promoting electoral democracy. The classic literature on the "boomerang effect" on transnational advocacy networks also suggests that TSMOs promote basic human rights at the center of liberal democracy (Keck and Sikkink, 1998; Hafner-Burton and Tsutsui 2005; Kim 2013). IGOs and TSMOs have also been known to collaborate to promote effective election monitoring (Kelley 2012). Stated as a formal hypothesis:

Hypothesis 1: Electoral democracy diffuses through TSMO networks, ceteris paribus.

However, whereas IGOs and state leaders are most likely to intervene during elections and democratic reversals, the day-today work of TSMOs often focuses on other institutions. TSMOs do not have the state as their primary interlocutors, and instead promote avenues for social and political advocacy beyond state structures. Many TSMOs are skeptical of the ability of electoral institutions to promote positive political change, since officials may be "captured" by elite interests that oppose their grassroots agenda (Smith et al., 2015). TSMOs often frame their work as "counter-hegemonic." The organizational culture of many TSMOs is non-hierarchical and seek consensus-building rather than decision-making by elected or appointed representatives (Smith 2004; Della Porta 2005). For example, the World Social Forums explicitly seek to cultivate "open spaces" for deliberation, critical dialogue, and networking among diverse social movements (Smith et al., 2013). The participatory governance model internal to many TSMOs involves the diffusion of a normative preference for dialogue, deliberation, and trust-

${ }^{18} \mathrm{Dahl}$ (1973) famously theorized two dimensions of "polyarchy", contestation and inclusiveness. For empirical evidence of these two dimensions, see Coppedge et al. (2008). 
building that is central to participatory democracy.

Beyond the normative diffusion of participatory values, TSMO linkage can provide an environment for the diffusion of specific participatory governance practices. For example, at the first World Social Forum in Porto Alegre, Brazil, TSMO representatives from countries around the world were exposed to and discussed the city's practice of participatory budgeting, in which ordinary citizens are given input into the municipality's budget practices. This practice was then carried back to WSF participants' home countries (Teivainen 2002). Thus, we expect TSMOs to especially diffuse people-centered ideas and institutions of participatory democracy, or direct citizen control of government and civil society participation. This is in fact one of the main stated goal of several TSMOs, such as the International Observatory of Participatory Democracy and Democracy International. Internally, TSMOs' participatory governance model can be pre-figurative for developing democratic culture. Externally, TSMOs' advocacy and mass action campaigns reflect a widespread commitment to broadening "inclusion" (political participation of the masses) if not improving "contestation" per se.

Hypothesis 2: Participatory democracy diffuses through TSMO networks, ceteris paribus.

Finally, how TSMOs promote electoral democracy should directly relate to their organizational character. A contrast with traditional democratic diffusion through democratic states or IGOs is illustrative. These "top-down" processes of diffusion, which tend to focus on the specific institution of free and fair elections, typically involve socialization and electoral negotiations among politicians, political parties, and high-level diplomats (Freyburg 2015). Elites are more likely to value institutional solutions to political problems and advocate changing a country's institutional structure.By contrast, TSMOs are grassroots organizations not typically made up of professional politicians or bureaucrats. As private citizens outside the governmental apparatus, TSMO activists value aspects of democracy that facilitate their work as political activists, in particular protections for freedom of association and freedom of expression. Whatever other policy goals TSMOs harbor, all TSMOs seek a political system open enough for them to operate and achieve political change through citizen action. Some TSMOs have advancing these freedoms as their primary goal, including Reporters without Borders and the International Freedom of Expression Exchange (IFEX). Since 2007, the World Movement for Democracy, a transnational network of democracy activists, has sought to counter state-led efforts and repressive laws that restrict civil society organizations from operating. ${ }^{19}$

Hypothesis 3: Freedom of association and freedom of expression (free and fair elections) diffuse more (less) strongly through TSMO networks, ceteris paribus.

TSMOs may diffuse other components and dimensions of democracy as well, for instance promoting the protection of

\footnotetext{
${ }^{19}$ See "Defending Civil Society", World Movement for Democracy, https://www. movedemocracy.org/defending-democratic-space/defending-civil-society, accessed June 27, 2021.
}

human rights or the rule of law (liberal democracy) and promoting egalitarian and deliberative democratic norms. However, in the interest of space, we focus on the above aspects of democracy as a starting point for examining these "bottom up" processes of democratic diffusion.

\section{DATA AND METHODS}

\section{Dependent Variables: Varieties of Democracy}

As mentioned previously, most prior studies of democratic diffusion have relied on Polity IV or other binary measures (Cheibub et al., 2010; Boix, Miller, and Rosato 2012). Relying on such minimalist measures would prevent us from testing whether TSMOs are better are promoting non-electoral elements of democracy. So we draw on the Varieties of Democracy (V-Dem) project, ${ }^{20}$ which recognizes that political systems can be "democratic" in a variety of ways that are not necessarily additive or unidimensional, and may sometimes conflict. ${ }^{21}$ For instance, whereas electoral democracy is often majoritarian, liberal democracy gives primacy to the rule of law and protecting the rights of minorities even if this protection goes against public opinion. Moves towards greater electoral democracy might undermine a country's level of liberal democracy, and vice versa.

V-Dem identifies five dimensions of democracy: electoral, liberal, participatory, deliberative, and egalitarian. Each dimension combines several indicators that are either constructed from publicly available data or record the opinions of country experts. To test our first hypothesis, we use V-Dem's electoral democracy score (what V-Dem calls polyarchy). Electoral democracy comes closest to the traditional Western notion of democracy, wherein rulers are made responsive to citizens through free and fair elections. For elections to be truly free and fair, an electoral democracy must also protect freedom of expression and association. Thus, the polyarchy score is made up of five indicators: elected officials, free and fair elections, suffrage, free expression, and freedom of association.

To test our second hypothesis, we use V-Dem's participatory democracy component score, which captures the degree to which a government "emphasizes active participation by citizens in all political processes, electoral and non-electoral." Institutions of direct democracy and active citizen engagement in civil society, rather than representation and delegation, are preeminent. ${ }^{22}$

\footnotetext{
${ }^{20}$ For an introduction to the V-Dem data, see Lindberg, (2014) and Coppedge et al. (2018).

${ }^{21}$ The correlation between these five democratic dimensions varies $(\approx 0.5-0.90)$. Yet even small differences in democracy measures can significantly affect results as differences center on contested cases (Cheibub et al., 2010).

${ }^{22}$ Given that one objective of this research is to distinguish impacts on electoral and participatory democracy, we use V-Dem's "participatory component" index that focuses exclusively on participatory democracy rather than its top-level "participatory democracy" score that combines the participatory component and the polyarchy score.
} 
To test our third hypothesis, we use three of the five polyarchy components. The first index is free and fair elections, which measures a country's degree of electoral integrity. The second index is freedom of association, measuring the ability of opposition parties and civil society groups to form and operate freely. The third index is freedom of expression, measuring a country's protections for freedom of speech, press, and cultural and academic expression. If our third hypothesis is correct, TSMOs diffuse freedom of association and expression, but not necessarily free and fair elections. ${ }^{23}$

\section{Key Diffusion Variables: Transnational Social Movement Organization Scores}

For our primary independent variable, we rely on the Transnational Social Movements Organizations Dataset (TSMOD), ${ }^{24}$ which contains biennial data on country-level membership and a wide range of other characteristics of TSMOs from 1953 through 2013, based on a combination of self-reports by organizations in response to an annual survey, as well as independent research by the editors of the Yearbook of International Organizations and TSMOD coders (Smith and Wiest 2012). ${ }^{25}$

As with any large-scale cross-national dataset, the data comes with important limitations and are only as good as its main source, the Yearbook. The data is likely biased towards larger organizations, and those without an interest in concealing their activities. $^{26}$ The data also only contains information on formal TSMOs and does not include more informally organized transnational social movements who may also play an important role in democratic diffusion. We have no ex ante reason to expect that these biases in the data should systematically bias the data towards supporting our findings, and if anything expect that the exclusion of most informal social movements should increase measurement error and make it more difficult to identify a statistically significant effect. However, findings based on this data should be appropriately caveated based on the limitations of the data source.

We use the country-membership variables from TSMOD to construct separate spatial lag variables for each type of democracy, with the "distance" between countries defined in

\footnotetext{
${ }^{23}$ In our online appendix we report tests with all five of V-Dem's "top-level" democracy indexes as well as all five components of the polyarchy index. The results are substantively similar.

${ }^{24}$ For more details on the TSMO dataset, see Smith, Plummer, and Hughes (2017) and Smith et al. (2018).

${ }^{25} \mathrm{We}$ interpolate missing (even) years assuming that a country reported as being a member of a TSMO will remain so until the data reports them as not being one. Some TSMOs also stop reporting any country memberships for periods of time. We assume that this is due to reporting bias, not to a genuine drop to zero members. If a TSMO changes from reporting members to reporting no members, yet the TSMO itself continues in operation we assume that countries that were members before the change remain members until the TSMO reports otherwise. As shown in the online appendix, the results are robust when we run on non-imputed/ non-corrected data.

${ }^{26}$ This reporting bias is likely more severe in the last years of the sample, in response to state efforts to restrict TSMOs.
}

terms of their degree of connectivity through TSMOs. Specifically, our spatial lag variables measure the weighted average of the level of the relevant $\mathrm{V}$-Dem variable in all states connected to the target state by at least one TSMO link. For country $i$ connected to countries $j=(1,2,3, n)$ at time $t$, TSMODemLag equals:

$$
\text { TSMODemLag }_{i t}=\sum_{j=1}^{n}\left(\frac{\operatorname{link}_{i j t}}{\operatorname{link}_{i t}} * \operatorname{Dem}_{j t}\right)
$$

where $D_{e m}$ is the level of democracy in country $j$ at time $t$, link $k_{i j t}$ is the number of shared TSMO memberships between countries $i$ and $j$, and $\operatorname{link}_{i t}$ is the number of shared TSMO memberships between country $i$ and all other countries. We thus assume all TSMO links matter, but that "democratic senders" are "closer" to country $i$ if they account for more of country $i$ 's TSMO links.

\section{Control Variables}

We control for some of the most prominent alternative explanations for democratization in the literature, while still maintaining a parsimonious model. ${ }^{27}$ We control for socioeconomic modernization with GDP per capita (logged). ${ }^{28} \mathrm{We}$ include two controls for period effects or temporal clustering. The first is a dummy variable for the Cold War period (equal to 1 for years up to 1991, and 0 otherwise) to account for structural changes in the global geopolitical situation during the period under study (1953-2013). The second is relative democratic economic performance, measured as the correlation between polyarchy and GDP per capita growth over the past 5 years. ${ }^{29}$

To address the "conflicting neighbor problem", we control for two other well-known spatial lags. First, geographic diffusion measures the average democracy score of all neighbors sharing a land border or within 400 miles by sea. ${ }^{30}$ To control for democratic diffusion through IGO networks, we control for the IO Score, replicating Pevehouse (2005)'s method with an expanded list of IGOs and the relevant V-Dem score. ${ }^{31}$ Finally, we control for the logged Number of TSMOs present in a country to ensure any democratic diffusion through TSMOs is not solely due to TSMO exposure. Table 1 contains summary statistics for all these variables.

\footnotetext{
${ }^{27}$ Following the methodological advice of Achen (2005) and Clarke (2005). We conduct a series of sensitivity tests to rule out concerns of omitted variable bias (see below on robustness checks).

${ }^{28}$ The GDP per capita variable is primarily from the Maddison Project database (Bolt et al., 2018). We use similar data from several sources such as the World Bank to fill in missing data.

${ }^{29}$ The measure follows Miller (2016), who finds that democracy diffuses more when democracies do well economically. This variable is a more robust predictor of temporal clustering than Gunitsky (2014)'s hegemonic shock variable.

${ }^{30}$ Data on geographic contiguity comes from Stinnett et al. (2002).

${ }^{31}$ We identify IGO networks by updating the COW IGO data of Pevehouse, Nordstrom, and Warnke (2004) which is missing years before 1965 and after 2005 We then expand the list of IGOs behind ioscore past 1992 (the end of Pevehouse' sample) to include those added by Teorell (2010) and identified from the FIGO data of Volgy et al. (2008).
} 


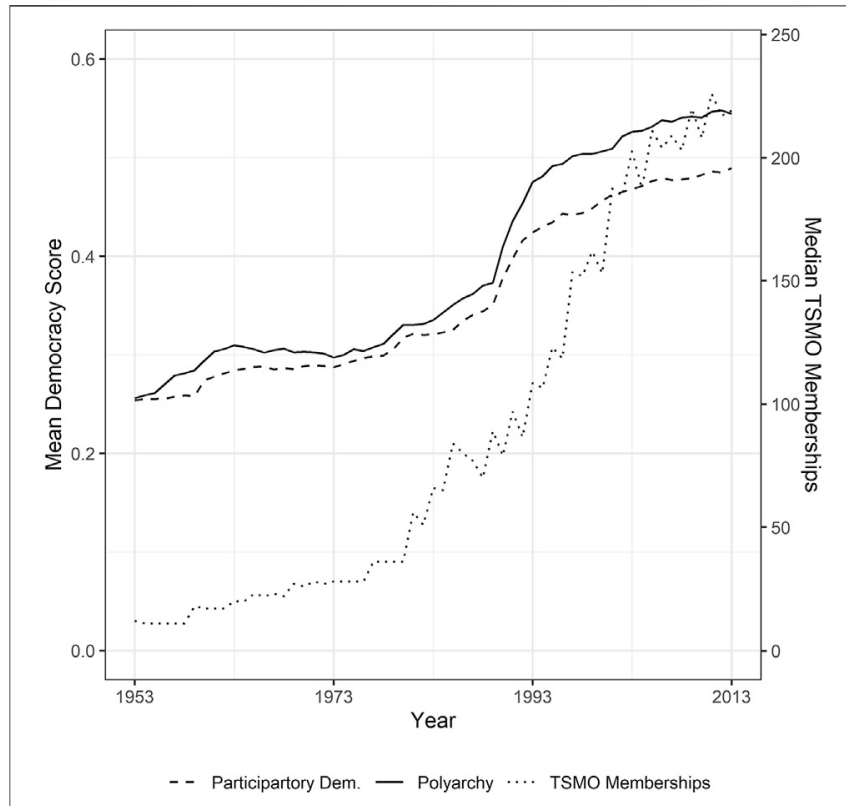

FIGURE 1 | Trends in TSMO membership, polyarchy, and participatory democracy.

\section{Model Specification}

Given that our dependent variables are continuous, we use OLS linear regression for our primary statistical models. To address non-independence of observations, we use Huber-White robust standard errors clustered by country. We also include country fixed effects in all models to control for unobservable timeinvariant differences across countries (such as colonial history, conditions at independence, etc.), thus our estimates pertain to "within" country variation over time.

\section{FINDINGS}

Initial descriptive analysis of the data shows a strong correlation between rising TSMO memberships and increasing levels of democracy globally. Figure 1 depicts these global trends over time, showing the median number of TSMO memberships per country and the global average polyarchy and participatory democracy scores. In particular, TSMO memberships and democracy scores jump at the end of the Cold War. This fits our expectations of TSMO activity as a potential source of democratic diffusion but also highlights the importance of appropriately modeling to address potential reverse causality and omitted variable bias, as we do in our primary models and robustness checks below.

We report our main results on country democracy levels in Table 2. The TSMO spatial lags are always positive and statistically significant across all five models, indicating that TSMO diffusion increases levels of polyarchy, participatory democracy, free and fair elections, freedom of association, and freedom of expression. The IO Score and geographic diffusion variable are also a significant predictor of all five dependent variables. As for the other controls, neither the
Cold War nor recent democratic economic performance has a significant effect on any democratic dimension. GDP per capita, our proxy for economic development, is a significant predictor of the electoral dimensions of democracy (models 1 and 3), but not of the non-electoral dimensions. ${ }^{32}$ Finally, our measure of the number of TSMOs present in a country is insignificant across all but one model, and in fact is negatively signed; TSMO presence alone does not appear to promote democracy.

These results support both $\mathrm{H} 1$ and $\mathrm{H} 2$. Both electoral and participatory democracy diffuse through TSMOs. However, the effects are stronger and more significant for participatory democracy. The TSMODemLag consistently has a larger coefficient than other diffusion variables on participatory democracy. While TSMOs initially seem to strongly diffuse most dimensions of democracy, this effect is strongest along democracy's participatory dimension. Figure 2 below shows the marginal effects of TSMO diffusion on polyarchy and participatory democracy by plotting the predicted level of these two dependent variables across Z-score standardized values of the TSMO diffusion variables with all other control variables held at their mean and the country fixed-effect set at the median. Moving from two standard deviations below the mean TSMO participatory democracy diffusion to two standard deviations above the mean entails a predicted increase of nearly 0.3 in participatory democracy, while the same change in TSMO diffusion of polyarchy increases predicted polyarchy by 0.2 . Both these increases are certainly substantive. A 0.2 difference in polyarchy is roughly equivalent to the difference between Germany and Nepal's level of polyarchy in 2018. But a difference of 0.3 in participatory democracy is roughly the difference between Germany and Somalia.

The results of Models 3 through 5, also shown in Table 2, provide support for $\mathrm{H} 3$, though the picture is more complicated than our hypothesis initially proposed. The TSMO diffusion variable positively affects all three components of polyarchy tested, against our expectation that TSMO diffusion would only affect freedom of expression and freedom of association. However, while the TSMO score significantly affects all three measures, its effect its strongest and most significant on the measure of freedom of association. ${ }^{33}$

\section{Reverse Causality: Is the Transnational Social Movement Organization Effect due to Already-Improving Democracies?}

These results provide strong initial evidence for a positive effect of TSMO democratic diffusion. However, it is possible that these results are due to endogeneity or reverse causation. We would first note that TSMO networks appear to be less

\footnotetext{
${ }^{32}$ This result is consistent with the recent findings of Knutsen et al. (2019). ${ }^{33}$ However, a $Z$ test of equality of coefficients (Paternoster et al., 1998) indicates that the coefficient for free and fair elections is not significantly lower than either the free association or free expression coefficients.
} 
TABLE 1 | Summary statistics on primary variables.

\begin{tabular}{|c|c|c|c|c|c|}
\hline Variable & $\mathbf{n}$ & Mean & Std.Dev & Min & Max \\
\hline Polyarchy & 9,847 & 0.398673 & 0.28885 & 0.008 & 0.948 \\
\hline Participatory democracy & 9,810 & 0.365827 & 0.213167 & 0.019 & 0.887 \\
\hline Free and fair elections & 9,867 & 0.686523 & 0.449362 & 0 & 1 \\
\hline Free association & 9,867 & 0.496791 & 0.33998 & 0.019 & 0.957 \\
\hline Free expression & 9,867 & 0.517587 & 0.332673 & 0.012 & 0.99 \\
\hline TSMO diffusion score & 9,210 & 0.506011 & 0.168345 & 0 & 0.736477 \\
\hline IO score & 8,802 & 0.484605 & 0.264514 & 0 & 0.9315 \\
\hline Global dem. Econ. Perf & 8,752 & 0.04332 & 0.17808 & -0.31238 & 0.435854 \\
\hline Regional democracy level & 8,752 & 0.387931 & 0.218765 & 0 & 0.930907 \\
\hline Cold war & 9,872 & 0.59613 & 0.490697 & 0 & 1 \\
\hline Number of TSMOs (log) & 9,210 & 4.05285 & 1.41485 & 0.69315 & 0.693147 \\
\hline GDP per capita (log) & 8,749 & 8.516368 & 1.161651 & 4.89784 & 12.57802 \\
\hline
\end{tabular}

TABLE 2 | Main regression results.

\begin{tabular}{|c|c|c|c|c|c|}
\hline & \multicolumn{5}{|c|}{ Dependent variable } \\
\hline & Polyarchy & Participatory democracy & Free and fair elections & Free association & Free expression \\
\hline & (1) & (2) & (3) & (4) & (5) \\
\hline \multirow[t]{2}{*}{ TSMO diffusion } & $0.334^{\star}$ & $0.494^{\star \star}$ & $0.540^{\star \star \star}$ & $0.649^{\star \star \star}$ & $0.551^{\star \star \star}$ \\
\hline & $(0.136)$ & $(0.172)$ & $(0.162)$ & $(0.166)$ & (0.166) \\
\hline \multirow[t]{2}{*}{10 score } & $0.276^{\star \star \star *}$ & $0.206^{* \star}$ & $0.248^{* *}$ & $0.254^{* \star \star}$ & $0.289^{*+*}$ \\
\hline & $(0.076)$ & $(0.071)$ & (0.084) & $(0.070)$ & $(0.070)$ \\
\hline \multirow[t]{2}{*}{ Democracy econ. Perf } & 0.014 & 0.014 & 0.017 & 0.030 & 0.028 \\
\hline & $(0.019)$ & $(0.015)$ & $(0.025)$ & $(0.023)$ & $(0.024)$ \\
\hline \multirow[t]{2}{*}{ Geog. Diffusion } & $0.390^{\star \star \star *}$ & $0.365^{\star \star \star}$ & $0.363^{* \star \star}$ & $0.417^{\star \star \star \star}$ & $0.404^{\star \star \star \star ~}$ \\
\hline & $(0.077)$ & (0.082) & (0.078) & $(0.071)$ & (0.072) \\
\hline \multirow[t]{2}{*}{ Cold war } & -0.021 & -0.008 & -0.022 & 0.016 & 0.009 \\
\hline & $(0.018)$ & $(0.014)$ & $(0.020)$ & $(0.026)$ & $(0.024)$ \\
\hline \multirow[t]{2}{*}{ GDP per capita (log) } & $0.032^{\star}$ & 0.005 & $0.058^{\star \star}$ & 0.016 & 0.016 \\
\hline & $(0.014)$ & $(0.011)$ & $(0.019)$ & $(0.019)$ & (0.018) \\
\hline \multirow[t]{2}{*}{ Number of TSMOs (log) } & -0.010 & 0.006 & $-0.021^{\star}$ & -0.008 & -0.006 \\
\hline & $(0.007)$ & $(0.007)$ & $(0.010)$ & $(0.010)$ & $(0.011)$ \\
\hline \multirow[t]{2}{*}{ Constant } & -0.040 & 0.075 & -0.384 & -0.074 & -0.066 \\
\hline & $(0.161)$ & $(0.136)$ & $(0.223)$ & $(0.237)$ & $(0.220)$ \\
\hline$R^{2}$ & 0.853 & 0.855 & 0.806 & 0.809 & 0.800 \\
\hline Num obs & 8,472 & 8,490 & 8,472 & 8,490 & 8,490 \\
\hline
\end{tabular}

Robust clustered standard errors in parentheses. Country fixed effects used in all models but omitted from table for clarity.

${ }^{*} \mathrm{p}<0.05,{ }^{* *} \mathrm{p}<0.01,{ }^{* * *} \mathrm{p}<0.001$

susceptible to selection effects than IGO networks. Over the 1953-2013 period, whereas over $5 \%$ of country-years have no regional IGO memberships, only $0.7 \%$ of country-years have no TSMO memberships (almost all of these are at the beginning of the period). Incumbent regimes do not get to "choose their neighbors" to the same extent with TSMOs. Individuals, not states, become members of TSMOs. This means that civil society is the key intermediary, and state influence on TSMO membership can only work through restrictions on individual behavior or by expelling populations that are connected to TSMO networks. This is extremely hard to do. Even countries like North Korea, which are notoriously isolated and outside most IGOs, have seen a recent rise in TSMO memberships.
Nevertheless, strong states may certainly exercise some degree of control over TSMO presence. In Russia, Hungary, and Turkey in recent years democratic backsliding has been accompanied by closing space for TSMOs and other international organizations to operate within their borders (Carothers 2016). Thus, countries that welcome TSMOs may already be in the process of democratizing, and those that shut TSMOs out may be moving away from democracy.

How can we tease out this relationship? One piece of evidence in favor of the independent effect of TSMOs is that it is the spatial lag of TSMO democracy, not the number of TSMOs present in a country, which has the strongest effect on future levels of democracy. Countries with many TSMOs are no more likely to have high levels of democracy (along any of the dimensions 
TABLE 3 | Main models with lagged dependent variable.

Dependent variable

\begin{tabular}{|c|c|c|c|c|c|}
\hline & Polyarchy & Participatory democracy & Free and fair elections & Free association & Free expression \\
\hline & (1) & (2) & (3) & (4) & (5) \\
\hline TSMO diffusion & 0.015 & $0.054^{\star}$ & 0.047 & $0.060^{\star}$ & $0.067^{* \star}$ \\
\hline & $(0.023)$ & $(0.023)$ & $(0.032)$ & $(0.027)$ & $(0.026)$ \\
\hline Lagged DV & $0.917^{\star \star \star}$ & $0.927^{\star \star \star}$ & $0.848^{\star \star \star}$ & $0.915^{\star \star \star}$ & $0.927^{\star \star \star}$ \\
\hline & $(0.007)$ & $(0.005)$ & $(0.013)$ & $(0.007)$ & $(0.005)$ \\
\hline IO Score & $0.028^{* *}$ & $0.020^{\star}$ & $0.035^{* \star}$ & $0.027^{* \star}$ & $0.026^{* *}$ \\
\hline & $(0.009)$ & $(0.008)$ & $(0.014)$ & $(0.009)$ & $(0.008)$ \\
\hline Democracy econ. Perf & $0.022^{\star \star \star}$ & $0.019^{\star \star \star}$ & $0.019^{\star \star}$ & $0.043^{\star \star \star}$ & $0.038^{\star \star \star}$ \\
\hline & $(0.004)$ & $(0.003)$ & $(0.006)$ & $(0.006)$ & $(0.006)$ \\
\hline Geog. Diffusion & $0.038^{\star \star \star}$ & $0.033^{\star *}$ & $0.054^{\star \star \star}$ & $0.036^{\star \star \star}$ & $0.032^{\star \star}$ \\
\hline & $(0.011)$ & $(0.010)$ & $(0.015)$ & $(0.010)$ & (0.010) \\
\hline Cold war & -0.003 & 0.002 & -0.008 & 0.002 & $0.012^{\star \star}$ \\
\hline & (0.003) & $(0.002)$ & $(0.005)$ & $(0.005)$ & $(0.004)$ \\
\hline GDP per capita (log) & 0.002 & 0.001 & $0.008^{\star}$ & 0.002 & 0.0005 \\
\hline & $(0.002)$ & $(0.001)$ & $(0.003)$ & $(0.002)$ & $(0.002)$ \\
\hline Number of TSMOs (log) & 0.0005 & 0.001 & 0.001 & $0.004^{*}$ & $0.005^{\star \star \star}$ \\
\hline & $(0.001)$ & $(0.001)$ & $(0.002)$ & $(0.002)$ & (0.002) \\
\hline Constant & 0.001 & -0.024 & -0.035 & -0.044 & -0.062 \\
\hline & $(0.023)$ & $(0.018)$ & $(0.039)$ & $(0.035)$ & $(0.033)$ \\
\hline $\mathrm{R} 2$ & 0.977 & 0.978 & 0.947 & 0.971 & 0.972 \\
\hline Num. Obs & 8,471 & 8,490 & 8,471 & 8,490 & 8,490 \\
\hline
\end{tabular}

Robust clustered standard errors in parentheses. Country fixed effects used in all models but omitted from table for clarity.

${ }^{*} \mathrm{p}<0.05,{ }^{* *} \mathrm{p}<0.01,{ }^{* * *} \mathrm{p}<0.001$.
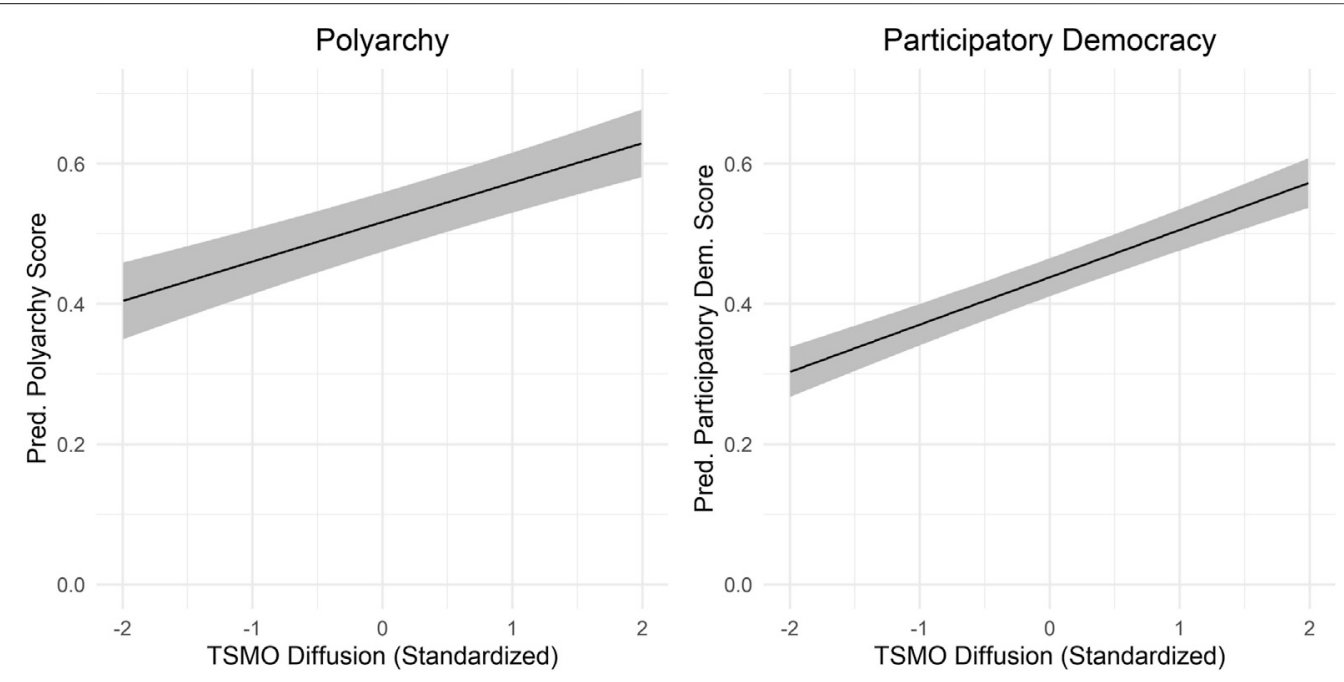

FIGURE 2 | Marginal effects of TSMO diffusion.

tested here) than those with few TSMOs. It is instead the weighted average level of democracy in other countries connected to the country in question through TSMO links that has a strong effect on democracy. This speaks to the specific mechanism of democratic diffusion through TSMO links, rather than a more general positive influence of TSMO presence. If the effect we are identifying is simply due to reverse causation due to greater openness to TSMO activity, we would expect this spurious effect to run through both the number of TSMOs and the TSMO diffusion variable.

However, authoritarian leaders may be able to discriminate between those TSMOs likely to diffuse democracy and those that are not. To account for the pre-existing level of democratic openness that may shape the opportunities for members of 
democratizing TSMOs to establish themselves we re-ran all our main models, this time including the lagged level of the dependent variable. Thus, in our tests measuring the effects of polyarchy at $\mathrm{t}$ we also include polyarchy at $\mathrm{t}-1$, and likewise for each of our other dependent variables.

The results, reported in Table 3, provide some interesting caveats on our initial findings. The effect of TSMO diffusion on polyarchy and free and fair elections is no longer statistically significant. However, the effects on participatory democracy, freedom of association, and freedom of expression remain positive and highly significant. Thus, while $\mathrm{H} 1$ appears less robust, $\mathrm{H} 2$ and $\mathrm{H} 3$ are strengthened by taking past levels of democracy into account. ${ }^{34}$ However, while $\mathrm{H} 3$ appears more robust, it is important to note that $\mathrm{Z}$ tests for difference in coefficients (Paternoster et al., 1998) between the models do not indicate a significant difference between TSMO diffusion of free and fair elections and either free association or freedom of expression. $^{35}$

Finally, it is possible that some degree of government openness to TSMO activity that is not captured either by the country's level of democracy or its control over civil society is explaining both our independent and dependent variable. Thus, we ran several diagnostic tests to determine to what degree our results would be perturbed by adding an unobserved confounding variable (such as some unspecified government openness to TSMOs). Following Imbens (2003) procedure, we replicated each of our main models 10,000 times, each time adding in a random simulated confounder with varying degrees of correlation with our dependent and main independent variables. We then measured whether our measure of TSMO diffusion remained a statistically significant predictor with the simulated confounder added.

Figure 3 shows the result of this testing for the three relationships between TSMO democratic diffusion and democratic change most significant in the main testing: participatory democracy, freedom of association and freedom of expression. The $x$-axis captures the level of correlation with the dependent variable, while the $y$ axis captures the level of correlation with the independent variable. The control variables included in our main model appear as crosses, while the curve is a smoothed value of the level of correlation necessary for a simulated confounder to eliminate the statistical significance of TSMO democratic diffusion. As the figures show, this level of correlation is quite high for all three variables, significantly higher than all but one of our control variables.

The exception is our binary measure of the Cold War period, which is highly correlated with both our independent and

\footnotetext{
${ }^{34} \mathrm{We}$ also tested for the potential effects of reverse causality by replicating our models over a series of increasing temporal lags. We present these results in the appendix. The relationships between TSMO diffusion and participatory democracy, freedom of association, and freedom of expression are all robust to these additional tests.

${ }^{35}$ For free association, $\mathrm{Z}=0.401, p=0.344$. For free expression $\mathrm{Z}=0.647, p=0.259$ (both $p$-values reflecting one-tailed tests).
}

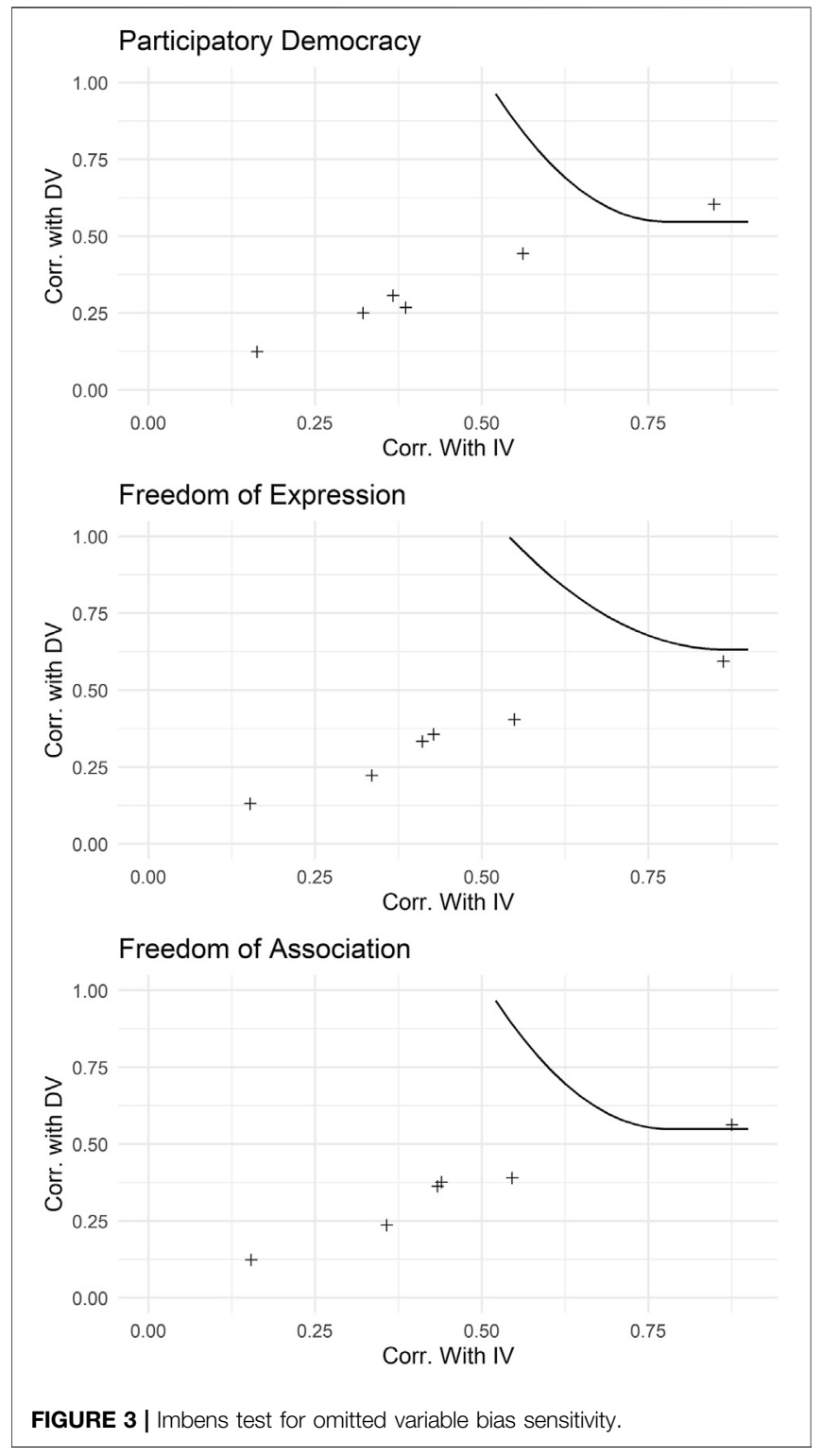

dependent variables. This suggests the importance of taking time seriously in our models, as both levels of TSMO connectedness and global democracy have increased on average during our period of study. To address this concern, we ran a series of robustness checks replicating our models with cubic polynomials of the time trend included. Our main results are robust to this model specification. Considering the centrality of the Cold War in the spread both of TSMOs and democracy we consider it unlikely that there is an additional sufficiently influential omitted variable to eliminate the significance of our primary relationships.

\section{Additional Robustness Checks}

We performed several additional robustness checks to ensure that the effects reported here are not artifacts of our modeling choices. 
We report the results of these tests in the Appendix. First, we reran all models with an alternate version of the independent variable that operationalizes TSMO links using Pevehouse's method for operationalizing IGO links. That is, TSMO Score measures the maximum average level of democracy in a TSMO linked to the country in that year. The results are the same in terms of sign and significance (see Table A3). Next, we ran all models with the first difference in democracy score at $t+1$ as the dependent variable, rather than absolute democracy score. Results are the same as the main results in terms of sign across all variables, though they lose statistical significance (see Table A4). The effect of TSMO diffusion thus appears to primarily effect levels of our different measures of democracy, while having little effect on rates of change along different dimensions of democracy. ${ }^{36}$

To ensure that our results are not being driven by marginal improvements in democratic quality within developed democracies we also re-ran tests on a sub-sample of countryyears excluding country-years above a democratic threshold (polyarchy > 0.5). The results further support $\mathrm{H} 1$ and $\mathrm{H} 3$ over $\mathrm{H} 2$. TSMO diffusion still significantly predicts polyarchy, freedom of expression, and freedom of association, but loses significance as a predictor of participatory democracy (see Tables A6).

Finally, the relative sparseness of our models necessitated conducting tests to address potential omitted variable bias. In particular, since both the number of TSMOs and global average level of democracy have been increasing over time it is possible that our results are simply due to the general time trend over our period of study. Thus, we ran a set of models with several additional potential confounders, including population, oil and natural gas rents, cubic polynomials of the time trend, and the annual global average level of democracy. Our results are substantively identical (See Table A7).

\section{CONCLUSION}

Whereas previous research has shown that democracy diffuses in general (whether through IGO or other contiguity networks), our article demonstrates that there is systematic variation in how democracy diffuses across different dimensions. Some but not all dimensions and components of democracy diffuse through TSMOs. TSMOs are only limited diffusers of the most common concept of democracy: electoral democracy. This is primarily because they do not appear to consistently diffuse electoral democracy's key component of free and fair elections. However, TSMOs are easy diffusion channels for participatory democracy, freedom of association, and freedom of expression.

These findings speak to scholars of TSMOs, democratization, and the spread of global norms. One interpretation of these findings that TSMO activities do not only or even primarily promote top-down forms of democracy defined by political

\footnotetext{
${ }^{36}$ Interestingly, when employing both alternate variables (the Pevehouse measure of TSMO diffusion and the first difference in democracy scores), the significance of our primary relationships returns.
}

responsiveness through the election of representatives, but instead promote a more "counter-hegemonic" discourse that argues for political order based on citizens' direct expression of political preferences (Smith et al., 2018). In the future, students of democracy and human rights would do well to further theorize mechanisms of political and social change that take into account salient variation in top-down and bottom-up processes. For example, scholars such as Brian Greenhill (2016) —as Pevehouse did for democracy-argue that IGO context promotes the diffusion of human rights. However, such studies of human rights protection have not similarly examined whether and how the TSMO context may help diffuse human rights protections.

Our work implies that policymakers interested in encouraging democracy should look beyond formal, top-down mechanisms and pay attention to the perhaps unruly and yet vibrant world of transnational social movement organizations. In a world of democratic decline, and one in which "anti-coup" norms in IGOs may also be declining (Tansey 2017), TSMOs may be important cross-national carriers of participatory democratic norms, practices, and mobilizational capacity.

The strength of the TSMO diffusion mechanism also speaks to the importance of policymakers defending the rights of TSMOs to operate cross-nationally. One of the most troubling developments in recent years has been the closing of civic space for local and transnational social movements by authoritarian and quasi-democratic regimes. This research indicates that cutting off this crucial mechanism of democratic diffusion is truly a crisis for global democracy that deserves our close attention.

\section{DATA AVAILABILITY STATEMENT}

All materials necessary to replicate the analysis and figures in this article are available at the article's Harvard Dataverse repository: https://doi.org/10.7910/DVN/FAIRXQ.

\section{AUTHOR CONTRIBUTIONS}

All authors listed have made an equally substantial, direct, and intellectual contribution to the work and approved it for publication. The authors are varying the order of their names as part of a series of joint projects.

\section{ACKNOWLEDGMENTS}

The authors would like to thank Jan Matti Dolbaum for editing the piece, and Jackie Smith and Svend-Erik Skaaning for excellent reviews. We would also like to thank Jackie Smith, Melanie Hughes, and all the participants in the "Transnational Social Movements and Global Change" workshop at the University of Pittsburgh in September 2018 and participants in the Political Science Research Workshop at Carnegie Mellon University in November 2018 for helpful comments on earlier versions of this paper. 


\section{REFERENCES}

Acemoglu, D., and Robinson, J. A. (2006). Economic Origins of Dictatorship and Democracy. New York: Cambridge University Press.

Acharya, A. (2004). How Ideas Spread: Whose Norms Matter? Norm Localization and Institutional Change in Asian Regionalism. Int. Organ. 58 (2), 239-275. doi: $10.1017 / \mathrm{s} 0020818304582024$

Achen, C. H. (2005). Let's Put Garbage-Can Regressions and Garbage-Can Probits where They Belong. Conflict Manage. Peace Sci. 22 (4), 327-339. doi:10.1080/ 07388940500339167

Ahlquist, J. S., and Wibbels., E. (2012). Riding the Wave: World Trade and FactorBased Models of Democratization. Am. J. Polit. Sci. 56 (2), 447-464. doi:10.1111/j.1540-5907.2011.00572.x

Bamert, J., Gilardi, F., and Wasserfallen, F. (2015). Learning and the Diffusion of Regime Contention in the Arab Spring. Res. Polit. 2 (3), 2053168015593306. doi:10.1177/2053168015593306

Bayer, M., Bethke, F. S., and Lambach, D. (2016). The Democratic Dividend of Nonviolent Resistance. J. Peace Res. 53 (6), 758-771. doi:10.1177/ 0022343316658090

Beck, N., Gleditsch, K. S., and Beardsley, K. (2006). Space Is More Than Geography: Using Spatial Econometrics in the Study of Political Economy. Int. Stud. Q 50 (1), 27-44. doi:10.1111/j.1468-2478.2006.00391.x

Beissinger, M. R. (2007). Structure and Example in Modular Political Phenomena: The Diffusion of bulldozer/rose/orange/tulip Revolutions. Perspect. Polit. 5 (02), 259-276. doi:10.1017/s1537592707070776

Boix, C. (2003). Democracy and Redistribution. New York: Cambridge University Press. doi:10.1017/cbo9780511804960

Boix, C., Miller, M., and Rosato, S. (2012). A Complete Data Set of Political Regimes, 1800-2007. Comp. Polit. Stud. 46 (12), 1523-1554. doi:10.1177/ 0010414012463905

Boli, J., and Thomas, G. M. (1999). Constructing World Culture: International Nongovernmental Organizations since 1875. Stanford: Stanford University Press.

Boli, J., and Thomas, G. M. (1997). World Culture in the World Polity: A Century of International Non-governmental Organization. Am. Sociological Rev. 62 (2), 171-190. doi:10.2307/2657298

Bolt, J., Robert, I., Herman, D. J, and Janvan Zanden, L. (2018). "Rebasing 'Maddison': New Income Comparisons and the Shape of Long-Run Economic Development," in Maddison Project Working Paper No. 10 (Groningen, Netherlands: University of Gronigen).

Boniface, D. S. (2002). Is There a Democratic Norm in the Americas? an Analysis of the Organization of American States. Gg 8 (3), 365-381. doi:10.2307/ 2780035010.1163/19426720-00803008

Braithwaite, A., Braithwaite, J. M., and Kucik, J. (2015). The Conditioning Effect of Protest History on the Emulation of Nonviolent Conflict. J. Peace Res. 52 (6), 697-711. doi:10.1177/0022343315593993

Brinks, D., and Coppedge, M. (2006). Diffusion Is No Illusion. Comp. Polit. Stud. 39 (4), 463-489. doi:10.1177/0010414005276666

Bunce, V., and Wolchik, S. L. (2011). Defeating Authoritarian Leaders in Postcommunist Countries. New York: Cambridge University Press. doi:10.1017/cbo9780511977404

Bunce, V. (2000). Comparative Democratization. Comp. Polit. Stud. 33 (6/7), 703-734. doi:10.1177/001041400003300602

Burgerman, S. D. (1998). Mobilizing Principles: The Role of Transnational Activists in Promoting Human Rights Principles. Hum. Rights Q. 20 (4), 905-923. doi:10.1353/hrq.1998.0035

Carothers, T. (2016). Closing Space for International Democracy and Human Rights Support. J. Hum. Rights Pract. 8 (3), 358-377. doi:10.1093/jhuman/ huw012

Carothers, T. (2015). Democracy Aid at 25: Time to Choose. J. Democracy 26 (1), 59-73. doi:10.1353/jod.2015.0010

Celestino, M. R., and Gleditsch, K. S. (2013). Fresh Carnations or All Thorn, No Rose? Nonviolent Campaigns and Transitions in Autocracies. J. Peace Res. 50 (3), 385-400. doi:10.1177/0022343312469979

Cheibub, J. A., Gandhi, J., and Vreeland, J. R. (2010). Democracy and Dictatorship Revisited. Public Choice 143 (1), 67-101. doi:10.1007/s11127-009-9491-2
Chen, J. (2010). Transnational Environmental Movement: Impacts on the green Civil Society in China. J. Contemp. China 19 (65), 503-523. doi:10.1080/ 10670561003666103

Chenoweth, E., and Stephan, M. J. (2011). Why Civil Resistance Works: The Strategic Logic of Nonviolent Conflict. New York: Columbia University Press.

Clark, A. M. (2001). Diplomacy of Conscience: Amnesty International and Changing Human Rights Norms. Princeton, NJ: Princeton University Press.

Clarke, K. A. (2005). The Phantom Menace: Omitted Variable Bias in Econometric Research. Conflict Manag. peace Sci. 22 (4), 341-352. doi:10.1080/ 07388940500339183

Cockram, R. (2017). Agents of Rights-Based Justice: Wangari Maathai and Kenya's Green Belt Movement. Global African Rev. 1 (1): 2-13.

Cole, W. M. (2017). World Polity or World Society? Delineating the Statist and Societal Dimensions of the Global Institutional System. Int. Sociol. 32 (1), 86-104. doi:10.1177/0268580916675526

Collier, D., and Levitsky, S. (1997). Democracy with Adjectives: Conceptual Innovation in Comparative Research. World Pol. 49 (3), 430-451. doi:10.1353/wp.1997.0009

Coppedge, M., Alvarez, A., and Maldonado, C. (2008). Two Persistent Dimensions of Democracy: Contestation and Inclusiveness. J. Polit. 70 (3), 632-647. doi:10.1017/s0022381608080663

Coppedge, M., Gerring, J., Altman, D., Bernhard, M., Fish, S., Hicken, A., et al. (2011). Conceptualizing and Measuring Democracy: A New Approach. Perspect. Polit. 9 (2), 247-267. doi:10.1017/s1537592711000880

Coppedge, M., Denison, B., Tiscornia, L., and Lindber, S. I. (2016). Varieties of Democratic Diffusion: Colonial and Neighbor Networks. V-Dem Working Paper 2 (2).

Coppedge, M., Gerring, J., Knutsen, C. H., Lindberg, S. I., Skaaning, S. E., Jan, T., et al. (2018). V-dem Codebook V8. Gothenberg, Sweden: V-Dem Institute University of Gothenburg.

Dahl, R. (1973). Polyarchy: Participation and Opposition. New Haven, CT: Yale University Press.

Davies, T. R. (2014). NGOs: A New History of Transnational Civil Society. Oxford University Press. doi:10.1093/acprof:oso/9780199387533.001.0001

Della Porta, D. (2014). Mobilizing for Democracy: Comparing 1989 and 2011. Oxford: Oxford University Press. doi:10.1093/acprof:oso/9780199689323.001.0001

Della Porta, D. (2005). Making the Polis: Social Forums and Democracy in the Global justice Movement. Mobilization: Int. Q. 10 (1), 73-94. doi:10.17813/ maiq.10.1.vg717358676hh1q6

Dodson, J., and Dong, G. (2016). Introduction. Quat. Int. 426, 1-14. doi:10.1016/ j.quaint.2016.11.041

Dodson, K. (2015). Globalization and Protest Expansion. Soc. Probl. 62 (1), 15-39. doi:10.1093/socpro/spu004

Donno, D. (2010). Who Is Punished? Regional Intergovernmental Organizations and the Enforcement of Democratic Norms. Int. Org. 64 (4), 593-625. doi:10.1017/s0020818310000202

Doorenspleet, R. (2005). Democratic Transitions: Exploring the Structural Sources of the Fourth Wave. Boulder, CO: Lynne Rienner Publishers.

Freyburg, T. (2015). Transgovernmental Networks as an Apprenticeship in Democracy? Socialization into Democratic Governance through CrossNational Activities. Int. Stud. Q. 59 (1), 59-72. doi:10.1111/isqu.12141

Gallo-Cruz, S. (2012). "Organizing Global Nonviolence: The Growth and Spread of Nonviolent INGOS, 1948-2003," in Nonviolent Conflict and Civil Resistance (Emerald Group Publishing Limited), 213-256. doi:10.1108/s0163-786x(2012) 0000034012

Gbowee, L. (2011). Mighty Be Our powers: How Sisterhood, Prayer, and Sex Changed a Nation at War. New York, NY: Beast Books.

Gift, T., and Krcmaric, D. (2017). Who Democratizes? Western-Educated Leaders and Regime Transitions. J. Conflict Resolution 61 (3), 671-701. doi:10.1177/ 0022002715590878

Gleditsch, K. S. (2002). All International Politics Is Local: The Diffusion of Conflict, Integration, and Democratization. Ann Arbor: University of Michigan Press. doi:10.3998/mpub.17068

Gleditsch, K. S., and Ward, M. D. (2006). Diffusion and the International Context of Democratization. Int. Org. 60 (04): 911-933. doi:10.1017/ S0020818306060309 
Gleditsch, K. S., and Rivera, M. (2017). The Diffusion of Nonviolent Campaigns. J. Conflict Resolution 61 (5), 1120-1145. doi:10.1177/0022002715603101

Goldring, E., and Greitens, S. C. (2020). Rethinking Democratic Diffusion: Bringing Regime Type Back in. Comp. Polit. Stud. 53 (2), 319-353. doi:10.1177/0010414019852701

Greenhill, B. (2016). Transmitting Rights: International Organizations and the Diffusion of Human Rights Practices. Oxford: Oxford University Press. doi:10.1093/acprof:oso/9780190271633.001.0001

Gunitsky, S. (2017). Aftershocks: Great powers and Domestic Reforms in the Twentieth century. Princeton: Princeton University Press. doi:10.1515/ 9781400885329

Gunitsky, S. (2014). From Shocks to Waves: Hegemonic Transitions and Democratization in the Twentieth Century. Int. Org. 68 (03), 561-597. doi:10.1017/s0020818314000113

Hafner-Burton, E. M., and Tsutsui, K. (2005). Human Rights in a Globalizing World: The Paradox of Empty Promises. Am. J. Sociol. 110 (5), 1373-1411. doi: $10.1086 / 428442$

Hafner-Burton, E. M., Mansfield, E. D., Pevehouse, J. C. W., and Pevehouse, J. C. (2015). Human Rights Institutions, Sovereignty Costs and Democratization. $\mathrm{Br}$. J. Polit. Sci. 45 (1), 1-27. doi:10.1017/S0007123413000240

Haggard, S., and Kaufman, R. R. (2016). Democratization during the Third Wave. Annu. Rev. Polit. Sci. 19, 125-144. doi:10.1146/annurev-polisci-042114-015137

Handy, Jim. (1994). Demilitarizing Community in Guatemala. Can. J. Latin Am. Caribbean Stud. 19 (37-38), 35-60. doi:10.1080/08263663.1994.10816705

Hawkins, D. (2008). Protecting Democracy in Europe and the Americas. Int. Org. 62 (3), 373-403. doi:10.2307/4007189810.1017/s0020818308080193

Huntington, S. P. (1991). The Third Wave: Democratization in the Late Twentieth century. Norman: University of Oklahoma Press.

Ignatow, G. (2012). "Transnational Environmental Activism," in The WileyBlackwell Encyclopedia of Globalization. doi:10.1002/9780470670590.wbeog909

Imbens, G. W. (2003). Sensitivity to Exogeneity Assumptions in Program Evaluation. Am. Econ. Rev. 93 (2), 126-132. doi:10.1257/000282803321946921

Jemadu, A. (2004). "Transnational Activism and the Pursuit of Democratization in Indonesia: National, Regional and Global Networks," in Transnational Activism in Asia: Problems of Power and DemocracyNicola Piper and Anders Uhlin (New York: Routledge), 167-185.

Keck, M. E., and Sikkink, K. (1998). Activists beyond Borders: Advocacy Networks in International Politics. Ithaca, NY: Cornell University Press.

Kelley, J. G. (2012). Monitoring Democracy: When International Election Observation Works, and Why it Often Fails. Princeton, NJ: Princeton University Press. doi:10.1515/9781400842520

Kim, D. (2013). "International Nongovernmental Organizations and the Global Diffusion of National Human Rights Institutions." Int. Org. 67 (03): 505-539. doi:10.1017/S0020818313000131

Knutsen, C. H., Gerring, J., Skaaning, S. E., Teorell, J., Maguire, M., Coppedge, M., et al. (2019). Economic Development and Democracy: An Electoral Connection. Eur. J. Polit. Res. 58 (1), 292-314. doi:10.1111/1475-6765.12282

Kopstein, J. S., and Reilly, D. A. (2000). Geographic Diffusion and the Transformation of the Postcommunist World. World Pol. 53 (1), 1-37. doi:10.1017/s0043887100009369

Leeson, P. T., and Dean, A. M. (2009). The Democratic Domino Theory: An Empirical Investigation. Am. J. Polit. Sci. 53 (3), 533-551. doi:10.1111/j.15405907.2009.00385.x

Levitt, B. S. (2006). A Desultory Defense of Democracy: OAS Resolution 1080 and the Inter-American Democratic Charter. Latin Am. Polit. Soc. 48 (3), 93-123. doi:10.2307/449047910.1353/lap.2006.0034

Lindberg, S. I., Coppedge, M., Gerring, J., and Teorell, J. (2014). V-Dem: A New Way to Measure Democracy. J. Democracy 25 (3), 159-169. doi:10.1353/jod.2014.0040

Mainwaring, S., and Pérez-Liñán, A. (2007). "Why Regions of the World Are Important: Regional Specificities and Region-wide Diffusion of Democracy," in Regimes and Democracy in Latin America: Theories and Methods. Editor G L. Munck (New York: Oxford University Press), 199-229.

Mandelbaum, M. (2002). The Ideas that Conquered the World: Peace, Democracy, and Free Markets in the Twenty-First century. 1st ed. New York: PublicAffairs.

Mansfield, E. D., and Pevehouse, J. C. (2006). Democratization and International Organizations. Int. Organ. 60 (1), 137-167. doi:10.1017/s002081830606005x

Markoff, J. (1996). Waves of Democracy: Social Movements and Political Change. Thousand Oaks, CA: Pine Forge Press.
Martínez-Torres, M. E., Rosset, P. M., and Peter, M. (2010). La Vía Campesina: the Birth and Evolution of a Transnational Social Movement. J. Peasant Stud. 37 (1), 149-175. doi:10.1080/03066150903498804

Meyer, J. W., Boli, J., Thomas, G. M., and Ramirez, F. O. (1997). World Society and the Nation-State. Am. J. Sociol. 103 (1), 144-181. doi:10.1086/231174

Miller, M. K. (2016). Democracy by Example? Why Democracy Spreads when the World's Democracies Prosper. Comp. Polit. 49 (1), 83-116. doi:10.5129/ 001041516819582946

Murdie, A. M., and Davis, D. R. (2012). Shaming and Blaming: Using Events Data to Assess the Impact of Human Rights INGOs1. Int. Stud. Q. 56 (1), 1-16. doi:10.1111/j.1468-2478.2011.00694.x

Nygård, H. M. (2017). The Role of International Organizations in Regime Transitions: How IGOs Can Tie a Dictator's Hands. Conflict Manage. Peace Sci. 34 (4), 406-430. doi:10.1177/0738894215599554

O'Loughlin, J., Ward, M. D., Lofdahl, C. L., Cohen, J. S., Brown, D. S., Reilly, D., et al. (1998). The Diffusion of Democracy, 1946-1994. Ann. Assoc. Am. Geogr. 88 (4), 545-574. doi:10.1111/0004-5608.00112

Pagnucco, R., and McCarthy, J. D. (1999). "Advocating Nonviolent Direct Action in Latin America: The Antecedents and Emergence of SERPAJ," in Nonviolent Social Movements: A Geographical Perspective. Editors S Zunes, L R. Kurtz, and S. B Asher (Malden, MA: Blackwell), 235-258.

Paternoster, R., Brame, R., Mazerolle, P., and Piquero, A. (1998). Using the Correct Statistical Test for the equality of Regression Coefficients. Criminology 36 (4), 859-866. doi:10.1111/j.1745-9125.1998.tb01268.x

Paxton, P., Hughes, M. M., and Green, J. L. (2006). The International Women's Movement and Women's Political Representation, 1893-2003. Am. Sociol. Rev. 71 (6), 898-920. doi:10.1177/000312240607100602

Pevehouse, J. C. (2002). Democracy from the Outside-In? International Organizations and Democratization. Int. Org. 56 (3), 515-549. doi:10.1162/ 002081802760199872

Pevehouse, J., Nordstrom, T., and Warnke, K. (2004). The Correlates of War 2 International Governmental Organizations Data Version 2.0. Conflict Manage. Peace Sci. 21 (2), 101-119. doi:10.1080/07388940490463933

Pevehouse, J. C. (2005). Democracy from above : Regional Organizations and Democratization. New York: Cambridge University Press. doi:10.1017/ cbo9780511491078

Pinckney, J. (2020). From Dissent to Democracy: The Promise and Peril of Civil Resistance Transitions. Oxford University Press. doi:10.1093/oso/ 9780190097301.001.0001

Poast, P., and Urpelainen, J. (2015). How International Organizations Support Democratization: Preventing Authoritarian Reversals or Promoting Consolidation? World Pol. 67 (1), 72-113. doi:10.1017/ s0043887114000343

Reimann, K. (2001). Building Networks from the outside in: International Movements, Japanese NGOs, and the Kyoto Climate Change Conference. Mobilization: Int. Q. 6 (1), 69-82. doi:10.17813/ maiq.6.1.h7112u322t021071

Reimann, K. D. (2006). A View from the Top: International Politics, Norms and the Worldwide Growth of NGOs. Int. Stud. Q 50 (1), 45-68. doi:10.1111/j.14682478.2006.00392.x

Russett, B. M., and Oneal, J. R. (2001). Triangulating Peace: Democracy, Interdependence, and International Organizations. New York: W.W. Norton \& Company.

Schmitz, H. P. (2004). Domestic and Transnational Perspectives on Democratization. Int. Stud. Rev. 6 (3), 403-426. doi:10.2307/ 369969710.1111/j.1521-9488.2004.00423.x

Schofer, E., and Longhofer, W. (2011). The Structural Sources of Association. Am. J. Sociol. 117 (2), 539-585. doi:10.1086/661593

Sharp, G. (2012). From Dictatorship to Democracy: A Conceptual Framework for Liberation. New York: New Press.

Sikkink, K., and Smith, J. (2002). "Infrastructures for Change: Transnational Organizations, 1953-93," in Restructuring World Politics: The Power of Transnational Agency and Norms. Editors S Khagram, J. Riker, and K. Sikkink (Minneapolis: University of Minnesota Press), 24-44.

Smith, J., Burns, R., and Miller, R. (2013). "The World Social Forums as Transformative Peacebuilding," in Globalization, Social Movements, and Peacebuilding. Editors J Smith and E. Verdeja (Syracuse, NY: Syracuse University Press), 207-234. 
Smith, J., Karides, M., Becker, M., Brunelle, D., Chase-Dunn, C., and Donatella, D. P. (2015). Global Democracy and the World Social Forums. New York, NY: Routledge. doi:10.4324/9781315636375

Smith, J. (1996). Organizing Global Action: Transnational Social Movements and World Politics. Ph.D. dissertation. South Bend (IN): University of Notre Dame.

Smith, J. (2008). Social Movements for Global Democracy. Baltimore, MD: Johns Hopkins University Press.

Smith, J., and Wiest, D. (2012). Social Movements in the World-System: The Politics of Crisis and Transformation. New York, NY: Russell Sage Foundation.

Smith, J. (2002). Bridging Global Divides? Int. Sociol. 17 (4), 505-528. doi:10.1177/ 0268580902017004003

Smith, J., Gemici, B., Plummer, S., and Hughes, M. M. (2018). Transnational Social Movement Organizations and Counter-hegemonic Struggles Today. Jwsr 24 (2), 372-403. doi:10.5195/jwsr.2018.850

Smith, J., Plummer, S., and Hughes, M. M. (2017). Transnational Social Movements and Changing Organizational fields in the Late Twentieth and Early Twenty-First Centuries. Glob. Networks 17 (1), 3-22. doi:10.1111/glob.12152

Smith, J. (2004). The World Social Forum and the challenges of global democracy. Global Networks 4 (4), 413-421. doi:10.1111/j.1471-0374.2004.00102.x

Smith, J., and Wiest, D. (2005). The Uneven Geography of Global Civil Society: National and Global Influences on Transnational Association. Social Forces 84 (2), 621-652. doi:10.2307/359847210.1353/sof.2006.0036

Spilimbergo, A (2009). Democracy and foreign education. The American Economic Review 99 (2), 528-543. doi:10.1257/aer.99.1.528

Starr, H. (1991). Democratic Dominoes. J. Conflict Resolution 35 (2), 356-381. doi:10.1177/0022002791035002010

Starr, H., and Lindborg, C. (2003). Democratic Dominoes Revisited. J. Conflict Resolution 47 (4), 490-519. doi:10.1177/0022002703252373

Steinhardt, H. C., and Wu, F. (2016). In the Name of the Public: Environmental Protest and the Changing Landscape of Popular Contention in China. China J. 75 (1), 61-82. doi:10.1086/684010

Stinnett, D. M., Tir, J., Diehl, P. F., Philip, S., Schafer, P., and Gochman, C. (2002). The Correlates of War (Cow) Project Direct Contiguity Data, Version 3.0. Conflict Manage. Peace Sci. 19 (2), 59-67. doi:10.1177/073889420201900203

Tansey, O. (2017). The Fading of the Anti-coup Norm. J. Democracy 28 (1), 144-156. doi:10.1353/jod.2017.0012

Tarrow, S. G. (2005). The New Transnational Activism. New York: Cambridge University Press. doi:10.1017/cbo9780511791055

Teivainen, T. (2002). The World Social Forum and Global Democratisation: Learning from Porto Alegre. Third World Q. 23 (4), 621-632. doi:10.1080/ 0143659022000005300
Teorell, J. (2010). Determinants of Democratization : Explaining Regime Change in the World, 1972-2006. New York: Cambridge University Press. doi:10.1017/ cbo9780511762727

Thomas, G. M., Meyer, J. W., Ramirez, F. O., and Boli, J. (1987). Institutional Structure: Constituting State, Society, and the Individual. Newbury Park, CA: Sage.

Torfason, M. T., and Ingram, P. (2010). The Global Rise of Democracy. Am. Sociol. Rev. 75 (3), 355-377. doi:10.1177/0003122410372230

True, J., and Mintrom, M. (2001). Transnational Networks and Policy Diffusion: The Case of Gender Mainstreaming. Int. Stud. Q 45 (1), 27-57. doi:10.1111/ 0020-8833.00181

Volgy, T. J., Fausett, E., Grant, K. A., and Rodgers., S. (2008). Identifying Formal Intergovernmental Organizations. J. Peace Res. 45 (6), 837-850. doi:10.2307/ 2764077210.1177/0022343308096159

Wejnert, B. (2014). Diffusion of Democracy: The Past and Future of Global Democracy. New York: Cambridge University Press.

Wejnert, B. (2005). Diffusion, Development, and Democracy, 1800-1999. Am. Sociol. Rev. 70 (1), 53-81. doi:10.1177/000312240507000104

Weyland, K. G. (2014). Making Waves: Democratic Contention in Europe and Latin America since the Revolutions of 1848. New York: Cambridge University Press. doi:10.1017/cbo9781107045279

Zhukov, Y. M., and Stewart, B. M. (2013). Choosing Your Neighbors: Networks of Diffusion in International Relations1. Int. Stud. Q. 57 (2), 271-287. doi:10.1111/ isqu. 12008

Conflict of Interest: The authors declare that the research was conducted in the absence of any commercial or financial relationships that could be construed as a potential conflict of interest.

Publisher's Note: All claims expressed in this article are solely those of the authors and do not necessarily represent those of their affiliated organizations, or those of the publisher, the editors and the reviewers. Any product that may be evaluated in this article, or claim that may be made by its manufacturer, is not guaranteed or endorsed by the publisher.

Copyright (c) 2021 Pinckney and Chin. This is an open-access article distributed under the terms of the Creative Commons Attribution License (CC BY). The use, distribution or reproduction in other forums is permitted, provided the original author(s) and the copyright owner(s) are credited and that the original publication in this journal is cited, in accordance with accepted academic practice. No use, distribution or reproduction is permitted which does not comply with these terms. 